\title{
Intra-operative frozen section diagnosis of the suspicious solitary pulmonary nodule, how can we improve the strike-rate?
}

\author{
R Govindraj, , F Chowdhry, K Ang, D Waller \\ From 23rd World Congress of the World Society of Cardio-Thoracic Surgeons \\ Split, Croatia. 12-15 September 2013
}

\section{Background}

To justify our policy towards suspicious solitary pulmonary nodules of intraoperative frozen section (IOFS) and not percutaneous biopsy, we evaluated its effectiveness and aimed to identify preoperative factors which may reduce unnecessary surgery for benign lesions.

\section{Methods}

$67(27 \%)$ of last 250 consecutive patients (36M:31F, mean age:67 yrs) discussed in MDT, operated for suspected cancer, underwent VATS nodule excision and IOFS. We reviewed perioperative data to determine effectiveness and performed multivariate analysis to identify factors predictive of malignant IOFS.

\section{Results}

The positive predictivity of IOFS was $100 \%$. Benign (including carcinoid) result was obtained in 25 patients (37\%) comprising Organizing pneumonia-6, Granulomatous inflammation-6, Hamartomata-6, Carcinoid-5, Non-granulomatous inflammation-1, Solitary Fibrous Tumour-1. Malignant diagnoses included Adenocarcinoma-28, Squamous cell carcinomas-11, Large cell-2, Small cell lung cancer-1. Preoperative CTPET was undertaken in 44 patients (66\%) Non-NSCLC NSCLC p value n 2542 Age 62[21] 71[13] 0.003 Male\% 4459.3 0.218 Smoker\% $6071.40 .335 \mathrm{Hx}$ of malignancy12 14.3 0.791 Location, \% 0.58 RUL 40 47.6 RML 16 4.8 RLL 28 23.8 LUL 1619 LLL $02.4>1$ lobe 02.4 Size,mm 15 [10.0] 20.0[10.0] 0.013 Spiculated,\% 36 90.5 0.001 SUV 2.9[2.0] 5.7[8.0] 0.012 In multivariate analysis, malignant IOFS result was associated with older patients (OR 0.94),

* Correspondence: drrohithg@yahoo.com

University Hospitals of Leicester, Glenfield Hospital, Leicester, UK with larger (OR 0.92) and more spiculated (OR 0.76) lesions on CT.

\section{Conclusion}

A more effective protocol of VAT excision with intraoperative diagnosis with a reduced number of benign results could be achieved by routine use of CTPET and a more conservative, surveillance approach to more rounded nodules smaller than $2 \mathrm{~cm}$.

Published: 11 September 2013

doi:10.1186/1749-8090-8-S1-O224

Cite this article as: Govindraj et al.: Intra-operative frozen section diagnosis of the suspicious solitary pulmonary nodule, how can we improve the strike-rate? Journal of Cardiothoracic Surgery 2013 8(Suppl 1): $\mathrm{O} 224$.

Submit your next manuscript to BioMed Central and take full advantage of:

- Convenient online submission

- Thorough peer review

- No space constraints or color figure charges

- Immediate publication on acceptance

- Inclusion in PubMed, CAS, Scopus and Google Scholar

- Research which is freely available for redistribution

Submit your manuscript at www.biomedcentral.com/submit
() Biomed Central

\section{()

(c) 2013 Govindraj et al; licensee BioMed Central Ltd. This is an Open Access article distributed under the terms of the Creative Commons Attribution License (http://creativecommons.org/licenses/by/2.0), which permits unrestricted use, distribution, and reproduction in any medium, provided the original work is properly cited. 